\title{
EVOLUTION AND ORIENTATION OF ISLAMIC EDUCATION IN INDONESIA AND MALAYSIA
}

\author{
Ali Mas'ud, Ah. Zakki Fuad, Achmad Zaini \\ UIN Sunan Ampel Surabaya - Indonesia \\ Corresponding author: ah.zakki.fuad@uinsby.ac.id
}

\begin{abstract}
Islamic education in Indonesia and Malaysia stemmed from the very same origin, pondok pesantren. However, they went different ways due to several drives. As madrasah transformed some forms of pondok pesantren, colonial and political context has shaped Islamic education in Indonesia and Malaysia. In Indonesia, education is administered in a separate ministry and finally formed a curriculum that enable graduates to endeavor not only in religious fields but also in all walks of life. Whereas Ministry of Malaysian Education regulate both national education and religious education all students in Indonesia and Malaysia, though, regardless of their schools, must study religion with different gradation. While Islamic instruction in Indonesian schools is supplied only to shape religious character, Malaysian schools strive to create an integration between Islamic and non-Islamic sciences. Pondok pesantrens too, have developed to a degree that differing features do occur, although they share several resemblances. Their private natures enable pondok pesantrens to improvise their education with different outcome and shape, but remain a deeply rooted in Islamic education in both countries.
\end{abstract}

Keywords: Islamic education, Indonesia, Malaysia, history.

\section{Introduction}

Indonesia and Malaysia have similar features in terms of their Islamic education, in addition to ethnic, geographical and religious similarities. They share common history of Islamic education which started in form of Pondok Pesantren several centuries ago, which underwent several dynamics during colonial period. As a result, both countries have dual system of education. This dual system is comprised 
of Islamic and so-called secular education which also includes duality in administration and funding. Both Islamic education were arguably exposed to radicalism in one way or another. ${ }^{1}$ Such a statement is a bold one and somewhat over generalization, but it should be taken as warning that to be well-thought. More recently, another challenge is underway as orientation of education shifts in such a way that employment goals now become dominant than ever considering the highly competitive job market as well as national leverage. This means that students should not only learn Islamic subjects but also sciences. However, there is also difference between the two countries in term of their Islamic education. Karel E. Steenbrink, for instance, stated that Indonesian pondok pesantren is more open to change, whereas its Malaysian counterpart tends to be 'defensive' and resistant to change. ${ }^{2}$

From the history and development of each country, colonial and political context has shape Islamic education in Indonesia administered in a separate ministry and finally formed a curriculum that enable graduates to endeavor not only in religious fields but also in all walks of life. Whereas mainstream madrasah in Malaysia firmly embraces the idea that Islamic education should produce 'Ulamā'. Nevertheless, both countries agree that all students in Indonesia and Malaysia, regardless of their schools, must study religion with different gradation. While Islamic instruction in Indonesian schools is provided only to craft students' Islamic character, Malaysian schools require a form of integration between Islamic and non-Islamic sciences. Similarly, Pondok pesantrens have evolved into a point that differing features do occur, although they share several resemblances. Their private natures enable pondok pesantrens in both countries to make innovation, but remain a deeply rooted Islamic education institutions. The difference on the direction and position of Islamic education between Indonesia and Malaysia reflects how Islam has unfolded in

\footnotetext{
1 For Indonesian account, please read Martin van Bruinessen, "Traditionalist and Islamist Pesantrens in Contemporary Indonesia," Farish A. Noor, Yoginder Sikand and Martin van Bruinessen (eds), The Madrasa in Asia: Political Activism and Transnational Linkages (Amsterdam: ISIM/Amsterdam University Press, 2008), pp. 217-246. For Malaysian account, please read Richard G. Kraince, "Reforming Islamic Education in Malaysia: Doctrine or Dialogue?," Robert W. Hefner (ed), Making Modern Muslims: the politics of Islamic education in Southeast Asia (Hawai'i: University of Hawai'i Press, 2009), pp. 106-140.

${ }^{2}$ Karel E. Steenbrink, Pesantren Madrasah Sekolab: Pendidikan Islam dalam Kurun Moderen (Jakarta: LP3ES, 1986), pp. xiv-xv.
} 
two countries due to internal political situation and international considerations.

\section{Historical Overview of Islamic Education in Indonesia and Malaysia}

Historically speaking Islamic education in Indonesia dates back to period long before national independence. The earliest form of Islamic education in Indonesia took shape in pondok pesantren (traditional Islamic boarding school) which taught mainly figh (Islamic jurisprudence), kalam (theology), tașawuf (sufism), and Arabic grammar. This informal system continued even when the Dutch assumed a sizeable control over the archipelago in the late $18^{\text {th }}$ Century. In fact, in many instances pondok pesantren served as resistance against Dutch colonialization of the archipelago. When the Dutch introduced schools, mainly for colonialization purposes, many Muslims refused to enroll because of this anti-colonialism stance as well as the absence of religious instruction in the newly founded schools. This situation changes in the early $20^{\text {th }}$ Century, as early as 1909 , when certain progressive Muslims started to adopt this schooling system and introducing some non-religious subjects such as mathematics and other exact sciences in addition to Islamic subjects in their schools. ${ }^{3}$ On the other hand, majority of pondok pesantren remained as it was with its informal education imitating the practice in Mecca and Cairo at that time from which the teachers graduated. ${ }^{4}$ This duality of education persisted after independence of Indonesia when education was administered by two ministries; the education function which was formerly managed by the Dutch then sustained by Ministry of Education; whereas Islamic education was under auspices of Ministry of Religious Affairs since its conception in 1946 until now. However, the ministry only played supervising role for the existing private madrasah in early period. There were two levels of madrasah; they are Sekolah Rendah Islam or Madrasah Tingkat Rendah (lower madrasah) for four years and Madrasah Lanjutan (advanced madrasah) for three

\footnotetext{
3 Hidayatullah Azra, "Islamic Education in Indonesia," Holger Daun and Reza Arjmand (eds), Handbook of Islamic Education (Cham: Springer International Publishing AG, 2018), p. 7.

4 Martin van Bruinessen, "Traditionalist and Islamist Pesantrens in Contemporary Indonesia," Noor (eds), The Madrasa in Asia, p. 220
} 
years. ${ }^{5}$ Pondok pesantren, however, remained untouched. They kept teaching Islamic subjects in informal manner with the curriculum they desired. It was until 1959 that the government decided to fully fund madrasah by taking over several privately funded madrasah or those funded by local government. ${ }^{6}$ Madrasah then styled in parallel of schools, namely Madrasah Ibtidaiyah (Elementary Islamic School), Madrasah Tsanawiyah (Junior Islamic High School) and Madrasah Aliyah (Senior Islamic High School). ${ }^{7}$ This eventually would open a whole lot of dynamics of Islamic education in Indonesia.

In term of curriculum, state-funded madrasah at this stage predominantly taught Islamic subjects and a few general sciences. At the same time, especially after regime change in 1967 some pondok pesantren started to adopted madrasah system along with its curriculum. They combined madrasah system in school hour and their own style of Islamic instruction in their dormitory. Further curriculum development happened in 1975 which changed the landscape of Indonesian education in general. A Joint decision of Minister of Education and Culture, Minister of Religious Affairs and Minister of Internal Affairs was issued in 1975. The decision enabled student mobility from school to madrasah at the way around. For instance, after finishing at Sekolah Dasar (elementary school), a student can continue education to Madrasah Tsanawiyah (secondary level madrasah). Likewise, students of madrasah have the same opportunity to continue schooling under Ministry of Education and Culture. Certainly, this required curriculum overhaul. As a consequence, madrasah teach the same national curriculum in addition to Islamic religious subject regulated by the Ministry of Religious Affairs (MoRA). ${ }^{8}$

Nowadays, schools under the management of the Ministry of Education and Culture comprise of $82 \%$, whereas madrasah and other religious education under the management of MoRA comprise of $18 \%$. Schools managed by Ministry of Education and Culture teach mainly general (secular) knowledge with only 2 hour in a week of compulsory religious subject. This is called as national curriculum. Before 1975,

\footnotetext{
${ }^{5}$ Steenbrink, Pesantren Sekolah dan Madrasah, pp. 91-93

6 Mohammad Kosim, "Madrasah di Indonesia (Pertumbuhan dan Perkembangan)," Tadris, 2, 1 (2007), p. 50.

7 Azra, "Islamic Education in Indonesia, p. 4,

8 Abbas Ghozali et al., Madrasah Education Financing in Indonesia (Jakarta: ACDP, 2013), p. 1.
} 
madrasah, usually located in pondok pesantren, mainly taught Islamic subjects. However, since Joint decision of Minister of Education and Culture, Minister of Religious Affairs and Minister of Internal Affairs in1975, madrasah teach the same national curriculum in addition to Islamic religious subjects. ' They are 'Aq̄idah (theology), the Quran and Hadith, Fiqh (Islamic jurisprudence), and history of Islam. The curriculum of madrasah therefore consists of $70 \%$ of national curriculum and $30 \%$ of Islamic subjects. In doing so, graduates of madrasah are given have the same opportunity with graduate of school to compete in education as well as employment.

However, this arrangement caused the decline of rigor in the Islamic competence of madrasah graduates because they only spend $30 \%$ of their schooling time studying Islam. This deficiency is somewhat covered when a student of Masrasah Aliyah chooses agama (religious studies) as his or her peminatan or jurusan (stream or major) in second year for which he or she will study Islam more. The delivery, though, remains in Bahasa Indonesia. However, if a student chooses one of other three streams, namely mathematics and natural sciences, language and cultural studies, and social humanities, then he or she will study less Islamic sciences in comparison. ${ }^{10}$ As a result, the main goal of madrasah in producing future 'Ulamā' is somehow unintentionally overlooked. ${ }^{11}$ As a correction measure, in 1987 onward Ministry of Religious Affairs opened some Madrasah Aliyah Negeri (MAN) which specially address this issue. These kinds of madrasah are dubbed as Program Khusus (PK, Special program) as the composition of their curriculum comprised of $70 \%$ Islamic subjects and 30\% general science with boarding system as in a pondok pesantren style. The graduates of these madrasah were projected to study Islam in Islamic universities in Indonesia and abroad. ${ }^{12}$ It was a success experiment, as many bright students opted to study in these madrasahs and they excelled in further studies in Islamic universities either in Indonesia or Middle Eastern Countries. This kind of madrasah is eventually adopted by many private foundations, including many pondok pesantrens. As for

\footnotetext{
${ }^{9}$ Ibid.

${ }^{10}$ For information about this stream, read example: Info Peminatan (Jurusan), the official website of MAN 1 Jakarta, http://www.man1.sch.id/ppdb2019/info.php

11 Nur Ahid, "Problem Pengelolaan Madrasah Aliyah dan Solusinya," Islamica, 4, 2 (March 2010), p. 338.

12 Kosim, "Madrasah di Indonesia, pp. 53-54.
} 
now, the number of MAN PK is 10 madrasahs across the archipelago, not to mention similar madrasahs in several pondok pesantrens.

In other equation, for Muslims who want to study exact sciences with Islamic environment and habituation, a madrasah called Madrasah Aliyah Negeri Insan Cendekia (MAN-IC) was established in the late 1990s with the patronage of BJ. Habibie, a leading Indonesian Muslim technocrat and scientist, who later became the President of Indonesia in 1998-1999. The ministry initially opened two pilot MAN-IC and they were successful as many of their graduates were admitted in many faculties of sciences in leading universities in Indonesia. ${ }^{13}$ Nowadays, the Ministry of Religious Affairs starts to multiply MAN-IC in provinces and jointly funds the operation with participating provincial governments. The number of MAN-IC up to now is 22 madrasahs scattered in many provinces in Indonesia.

In term of funding and management, government welcomes private institutions to open schools and madrasah with government agency acting as supervision and accreditation role. Many Islamic mass organizations, including Nahdlatul Ulama and Muhammadiyah also found schools and madrasah. ${ }^{14}$ Pondok pesantrens, which usually is usually affiliated to Muslim traditionalists such as Nahdlatul Ulama also found madrasah as previously explained. In such an arrangement, students will get additional Islamic religious instruction after school time. Some pondok pesantren nowadays also found schools (which is basically under administration of Ministry of Education with limited schooling hours for Islamic instruction) as well. This is not uncommon in Indonesia. They arrange their curriculum in such a way that both general (or secular) knowledge and Islamic teaching are delivered not only in classroom but also in dormitory after schooling hours. Alternatively, (or in combination), they extend schooling hours to accommodate certain Islamic instruction in addition to 2 hour obligatory religious studies in school. Recently, modernist Muslims also found their own version of pondok pesantren. The most notable example is pondok pesantren Darussalam Gontor Ponorogo. ${ }^{15}$ Muhammadiyah,

\footnotetext{
13 Makmuri Sukarno, "Mengembangkan Madrasah Aliyah Negeri Insan Cendekia Untuk Menjawab Tantangan Modernisasi, Demokratisasi Dan Globalisasi," Jurnal Kependudukan Indonesia, 9, 2 (December 2014), pp. 119-136.

${ }^{14}$ Ghozali, Madrasab Education Financing, p. 1.

15 Lance Castle, "Notes on the Islamic School at Gontor," Indonesia, 1, 1 (1966): pp. $30-45$.
} 
the major Muslim modernists organization, also opened several pondok pesantren under the name Muhammadiyah Boarding School (MBS). ${ }^{16}$ The last, but not the least, is the emergence of salafi pesantrens which differ in many ways from well-established traditional pondok pesantrens. Salafi originates from their commitment to following the salaf al-șalih (early pious generation) by submitting to the absolute literal word of the Qur'an and the sunna. This was part of the global expansion of the contemporary Salafi da'wa, closely allied with the Saudi Arabia-based sectarian brand of Islamic thought and practice, Wahhabism. ${ }^{17}$

Traditional pondok pesantren, too, undergoes dramatic changes. Some pondok pesantren maintain their autonomy in term of curriculum and funding. These kinds of pondok pesantren are called salaf (traditional). They use curriculum based on the Arabic turath books affiliated to Mazhab Shafii. Changes, however, do occur in these pondok pesantren as madrasah delivery system was adopted along with its classroom instruction, grading system, and management. The content of the curriculum, though, remains the same as they do not adopt government curriculum. They mainly excel on fiqh education, but some pondok pesantren also focus on different expertise, such as memorization of the Holy Quran and Islamic mysticism. Some of traditional pondok pesantren even provide high level of Islamic education that similar to general higher education, they call this as Ma'had Aly (Higher College) which started to operate in the 1990s and gained recognition of excellence among Muslim community in Indonesia. ${ }^{18}$ As a token of appreciation for this excellent practices, Ministry of Religious Affairs certified and acknowledged this education as part of formal education equivalent to formal higher education. Its graduates then will get bachelor degree. ${ }^{19}$

\footnotetext{
16 Ibnu Habibi, "Muhammadiyah Boarding School (MBS) Sebagai Alternatif Model Pesantren (Potret Pendidikan Islam di Era Kontemporer)," Proceedings of 1 st Annual Conference for Muslim Scholars (Ancoms) (Surabaya: Kopertais Wilayah IV Surabaya, 2017).

17 Noorhaidi Hasan, "The Salafi Madrasas of Indonesia," Noor (eds), The Madrasa in Asia, pp. 248-249

18 Nurul H. Maarif, Gamal Ferdhi and A. Suaedi, "Memecah Kebekuan Regenerasi Ulama," Gatra, 12 February 2006.

19 The Minister of Religious Affairs personally expressed his appreciation for the success of Ma'had Ali when he officially opened 13 Ma'had Ali on 30th of May 2016. See this news on NU online, 'Inilah 13 Ma'had Aly yang Diresmikan oleh Menteri
} 
In other equation, many pondok pesantrens accommodated government-style madrasah lock, stock and barrel. This accommodation also means the adoption of national curriculum into their privately funded madrasah. In fact, several madrasahs funded by government are located in pondok pesantrens from Madrasah Ibtida'iyah Negeri (MIN, State Elementary Islamic School), Madrasah Tsanawiyah Negeri (MTsN, State Junior High Islamic School) to Madrasah Aliyah Negeri (MAN, State Senior High Islamic School). Even some pondok pesantrens decided to open schools, especially Sekolah Menengah Pertama (SMP, Junior High School), Sekolah Menengah Atas (SMA, Senior High School), and Sekolah Menengah Kejuruan (SMK, Senior Vocational school). Indeed, these schools are administered by Ministry of Education, not Ministry of Religious Affairs. These schools in pondok pesantren usually provide additional Islamic subjects in addition to after hour Islamic instruction in dormitory. Although the idea of integration between Islamic science and so called general science has been around among progressive Muslims in the 1950s and 1960s, ${ }^{20}$ it was generally rejected, with some exceptions. It was not in implementation until much later and finally it is now quite common these days in many forms. The so called 'conservative turn' of Islam in Indonesia which started to crept in the early 1980s was only massively apparent after the fall of Suharto in 1998. This, in turn, hastened the Islamic symbolism in Indonesia in many realms, including in education sector. An episode that confirmed this is the passing of Law No. 2003 on National System of Education. This law requires schools, government as well and private schools, to provide religious educations to students based on their religions. ${ }^{21}$ However, in many ways, the contrast between Islamic and nationalist (secular) camps in Indonesian politics is still at large. Thus, while Islamic symbolism is apparent, certain Islamic-driven agendas should remain carefully crafted. Otherwise, it will face stiff oppositions from nationalist-secular groups.

Agama, https://www.nu.or.id/post/read/68634/inilah-13-mahad-aly-yang-diresmikan-oleh-menteri-agama

${ }^{20}$ Steenbrink, Pesantren, Madrasah Sekolah, p. 209-210.

21 Moch Nur Ichwan, "Towards a Puritanical Moderate Islam: The Majelis Ulama, Indonesia and the Politics of Religious Orthodoxy," Contemporary Developments in Indonesian Islam Explaining the 'Conservative Turn' (Singapore: Institute of Southeast Asian Studies, 2013), pp. 77-79. 
In another development, Starting 2008, Ministry of Education launched a program Sekolah Berbasis Pesantren (SBP, pesantren-based schools) to enhance the presence of schools in pondok pesantrens. ${ }^{22}$ Apparently, the main drive for this program is the desire to add Islamic instructions for students because of the limited hours for Islamic education in national schools, which is only 2 schooling hours per week, plus elective extra-curricular activities. This SBP program is seen as a transitional solution before regulatory change to add more religious instruction in schools, which a though one considering conflicting political and religious interests in Indonesia. ${ }^{23}$ This SBP program is, so far, a success due to willingness of many pondok pesantrens to participate. According to Steenbrink, the desire for providing Islamic education as well as keeping up with education needs of the society is a distinctive feature of Indonesian's pondok pesantren. That is why many pondok pesantrens open schools in addition to madrasahs. ${ }^{24}$

Similar to Indonesia, Islamic education has existed in Malaysia far before the formation of Malaysia. It is dated back as early as the $15^{\text {th }}$ Century CE right after the conversion of the Sultan of Malacca to Islam. The desire to studying Islam made a way for the coming of students for far places who wish to study Islam which in turn paved the creation of pondok in Malacca and the surrounding. ${ }^{25}$ Students who wish to continue their education used to go to Mecca as their destination which happened to have similar type of education, until the region was subdued under Wahhabi influence in early $20^{\text {th }}$ Century CE that students rerouted to Egypt's al-Azhar University for their study. This move, in turn, created major consequence to pondok system in Malaysia, as the returning graduates brought home al-Azhar types of education. They transformed many pondok into madrasah. This means

\footnotetext{
22 Nurochim, "Sekolah Berbasis Pesantren Sebagai Salah Satu Model Pendidikan Islam dalam Konsepsi Perubahan Sosial," Al-Tahrir, 16, 1 (May 2016), pp. 80-85.

${ }^{23}$ For earlier account on this sensitive issue of religious education in Indonesia, please read Lambert Kelabora, "Religious Instruction Policy in Indonesia," Asian Survey, 16, 3 (March 1976): pp. 230-248. For more recent account, especially after the fall of Suharto in 1998 onward, please read Moch. Tolchah, "The Political Dimension of Indonesian Islamic Education In The Post-1998 Reform Period," Journal of Indonesian Islam, 8, 2 (2014): pp. 284-298

${ }^{24}$ Steenbrink, Pesantren, Sekolah, Madrasah, pp. xii-xiii.

25 Ahmad Fauzi Abdul Hamid, "Islamic Education in Malaysia," Holger (eds), Handbook of Islamic Education, pp. 5-6.
} 
adopting structured system, combining Islamic instruction with western style pedagogy along with its classroom based on age groups and written examinations. Certainly, students had to learn modern sciences as well. ${ }^{26}$ However, this development could not happen without opposition. The tension on this regard was known as dichotomy between Kaum Muda (young faction, the reformers) and Kaum Tua (old faction, the conservatives). ${ }^{27}$ As a result, in the early $20^{\text {th }}$ Century the number pondok, that maintain traditional education as it was, drastically decreased. ${ }^{28}$ Madrasah became the choice for Malaysian Muslims for two reasons. Certainly, like in Indonesia, Malay Muslims refused to attend British school which had Christian orientation. Thus, an alternative should be sought, a school that instructed Islamic as well as general or secular science. That was madrasah. Madrasah at this stage had two types, in term of funding. Some madrasah were funded by sultanates, others by privates. Among the background of this duality is that he education is the domain of federal government, but religion is the purview of the states. Thus, religious education is in the grey area that were often contested in the past. This duality in Islamic education management persists until today, although with lesser complication. ${ }^{29}$

Another form duality also took place in Malaysian education system between national schools and Islamic schools which came into being during British Colonial rule in the Peninsula. As Malaysia gained independence in 1957, the education for the Malaysian Muslims became separated into three categories: traditional pondok and madrasah religious education; Malay vernacular schools; and the English schools efforts to unite these national and religious schools was on the table. The latter two categories offer secular education with nothing on religion being taught. ${ }^{30}$ These last two transformed into

\footnotetext{
26 Ibid.

27 Hiroko Kushimoto, "Islam and Modern School Education in Journal Pengasuh: Review of the Kaum Muda-Kaum Tua Dichotomy," Studia Islamika, 19, 2 (2012): pp. 207-250.

28 There are multiple explanations to this decline aside of reformist penetration, such as unfavorable education policy of British and the shortage of funding. Read, for example, Richard G. Kraince, "Reforming Islamic Education in Malaysia: Doctrine or Dialogue?," Hefner (ed), Making Modern Muslims, p. 113.

${ }^{29}$ Ibid., p. 114.

${ }^{30}$ Rosnani Hashim, "The reformation of Muslim education In Malaysia: ensuring relevance and overcoming challenges," International Symposium of Imam-Hatip (Vocational
} 
national schools whereas religious schools in term of madrasah and pondok remained as they were. ${ }^{31}$

The earliest step was the inclusion of Islamic instruction in national schools 1960. For a brief, this step accelerated the decline of madrasah. However, as Islamic resurgence swept Muslim world in 1970s, Malaysian Muslims gradually are more conscious than ever about their religion. ${ }^{32}$ Additionally, the 1977 First World Conference on Muslim Education in Mecca was the catalyst of change as it successfully raised the consciousness among Muslim countries of the urgent need for a new education system that integrate Western sciences with Islamic knowledge and teachings. ${ }^{33}$ Government was also requested to increase of Islamic instruction in national schools. Government, which also badly needed popular support, bowed down for the demand, and for non-Muslim moral education was inserted. Furthermore, special agency in the Ministry of Education called Bahagian Pendidikan Islam (BPI, Islamic Education Division) was set up to manage Islamic Education with the main goal of facilitating the integration of religious schools with the national educational system. This division has the responsibility on devising Islamic curriculum for national schools as well as supervising religious schools in general. ${ }^{34}$ Among of its result was an integrated curriculum. Kurikulum

Religious) Schools in their Centennial Anniversary (Istanbul, Turkey: November 23-25th 2013), p. 2

${ }^{31}$ Initially, the British opened schools in Malay peninsula though Christian missionary. It opened in urban areas. Rural Malay Muslims did not attend these schools for two reasons, fear of conversion to Christianity and lack of access. In response, British decided to open Malay vernacular schools for the Malays and incorporated Islamic study in the schools. For other ethnic groups, the British also founded schools, namely Tamil vernacular Schools and Chinese vernacular schools. The fifth of the schools was madrasah. Read, for instance, Nooraini Othman and Khairul Azmi Mohamad, "Eclectic Model in the Malaysian Education System," International Education Studies, 4, 4 (November 2011), p. 112.

32 Among the noticeable fruits of this surge of Islamic consciousness in Malaysia concern Muslim clothing, the flourish of Islamic banking in which Malaysia becomes one of its important hubs, and the concerns about halal products in a meticulous manner.

33 Rosnani Hashim, Suhailah Hussien and Juhasni Adila Juperi, "The Hikmah (Wisdom) Program: A philosophical inquiry for the teaching of Islamic education in Malaysia," Sa'eda Buang and Phyllis Ghim-Lian Chew (eds.), Muslim Education in the 21st Century: Asian perspectives (Oxon: Routledge, 2014), p. 125.

${ }^{34}$ Hamid, "Islamic Education in Malaysia, p. 9. 
Bersepadu Sekolah Rendah dan Menengah (KBSR and KBSM, The Integrated Curricula for Primary and Secondary Schools) were formulated in 1983 and 1989, respectively. ${ }^{35}$ It obliged Muslims students to study Islamic subjects in national schools. They were also additionally supplemented the choice of taking as electives such core religious subjects, even though they were in nonreligious streams. Among the subjects are Advanced Arabic language, Tasanwur al-IsIam (Islamic Worldview), al-Quran and al-Sunnah education and Islamic sharia. ${ }^{36}$ Government even bolstered Islamic education even further in national schools by launching Islamic-heavy curriculum, promulgating Falsafah Pendidikan Islam (FPI, Islamic Philosophy of Education), and other measures. Furthermore, J-QAF program that stands for the Jawi (the Malay-Jawi script or alphabets), the Quran, Arabic and the Fard 'Ayn was launched in 2005 to further empower Islamic education in primary schools. ${ }^{37}$

In other development, Malaysia also witnessed the revival of pondok as well as madrasah. The fact that many madrasah and pondok pay their allegiance to opposition faction (PAS) and some of their graduates involved in radicalism do not seem to erase its highly-valued position as the true provider of Islamic education among Malaysian Muslims. ${ }^{38}$ They too, by own initiatives, applied this integration of knowledge which resulted in the prolonged schooling hours. They want to ensure students were taught both the fard 'ayn sciences (knowledge on personal obligations that every Muslim needs to know and practice) and also the fard kifayah (knowledge on communal obligations), or the acquired sciences such as the humanities, social, exact, and applied sciences. Furthermore, another blow of criticism came of the Dr. Mahathir Muhammad who last year slammed about the heavy load of Islamic subjects in national schools, whereas English, mathematics and science are less studied in relative comparison, and planned for an education overhaul. ${ }^{39}$

\footnotetext{
${ }^{35}$ Hashim, "The Hikmah (Wisdom) Program: A philosophical inquiry, p. 125.

${ }^{36}$ Hamid, "Islamic Education in Malaysia, p. 9.

${ }^{37}$ F. Mat Zain, WK. Mujani, and IA Bakar, "The Islamic education and the 'j-QAF' program in Malaysia," Advances in Natural and Applied Sciences, 6, 3, special issue 2 (2012): pp. 310-315.

${ }^{38}$ Hamid, "Islamic Education in Malaysia, pp. 7-9.

39 The Straits Times, 'PM Mahathir to overhaul Malaysia's schools, saying too much focus on Islamic studies now,' https://www.straitstimes.com/asia/se-asia/pm-
} 
Nowadays, there are types of primary and secondary education in Malaysia, of which religious education is part. In Malaysian education system, there are at least four schools, namely; Sekolah Kebangsaan (SK, national schools) for primary and secondary levels, Sekolah Kebangsaan Agama (SKA, national religious secondary school) for elementary and secondary levels, Sekolah Agama Negeri (state religious schools) which is funded by states, not federal government, and Sekolah Agama Rakyat (SAR, people's religious schools) which are privately funded, but often receives funds from government. ${ }^{40}$ In such event, the school is named as Sekolah Agama Bantuan Kerajaan (SABK, government-aided religious schools) which are jointly controlled by the Ministry and the state religious authority or school's board of trustees. ${ }^{41}$ Islamic instructions are taught in these schools with different gradation with a curriculum devised by federal government. In addition to their own Islamic instructions, privately managed schools also use of the national curriculum so that their graduates can continue their studies in formal institutions of higher learning.

However, there is an unresolved problem concerning the destination for continuing education for graduates of these religious school to tertiary level in Malaysia because not many higher education institutions offered Islamic studies degree courses which accepted students who have only secondary level specialization in Islamic subjects. ${ }^{42}$ The reason for this intended shortage is employment prospect in a sense that the number of university graduates of a certain expertise should match its employment demands. Thus, since not many employment position for pure Islamic studies graduates, the number of university offering Islamic studies should be also limited. ${ }^{43}$ Thus, to deal with the issue, many graduates who still wish to concentrate in studying Islam find their way to continue their study abroad, especially in the Middle Eastern countries such as Egypt and Saudi Arabia. ${ }^{44}$

mahathir-to-overhaul-malaysias-schools-saying-too-much-focus-on-islam-studies-now, accessed on 22 December 2018.

40 Hamid, "Islamic Education in Malaysia, p. 7.

${ }^{41}$ Hashim, "The reformation of Muslim education In Malaysia, p. 7.

42 Ibid., p. 9.

43 Ibid.

${ }^{44}$ Ibid., p. 2 
The difference also relates to management and funding. While national schools and national religious secondary school administered and funded by Ministry of Education of federal government, state religious schools are administered and funded by their respective state Islamic agency. Whereas people's religious schools are established and funded by local Muslim community. ${ }^{45}$ In recent years, these people's religious schools and pondok are under scrutiny because many acts of radicalism were thought to have stemmed from these institutions. Some people's religious schools and pondoks have been alleged to become the breeding ground for radicalism since the 1980s. Federal government has made several measures to curb radicalism as a result in form of management, funding and curriculum. ${ }^{46}$ Nevertheless, this cannot prevent the blossoming of Islamic education in Malaysia, including pondok.

There has been adequate incentives and favorable government policy toward pondok school. Among the significant one in recent years was a government initiative which enable graduates of pondok school to pursue their tertiary education at higher education institutions. They now could study in universities to become engineers, lecturers, lawyers and judges for the sharia courts. ${ }^{47}$ While existing pondok survives with and without government assistance in one way or another, other type of pondoks also emerge. Some have international outlook in form of international Islamic schools equipped with curriculum which solely prepares graduates to study Islam abroad. In this case, they do not apply government curriculum. Others heavy emphasis on memorization of the Holy Quran, which in Malaysia is known as tahfiz institution, is mushrooming in recent years. ${ }^{48}$ Some tahfiz institutions only provide only tahfiz program, some combine with self-prepared

\footnotetext{
45 Azmel Tayeb, "The ups and downs of Islamic education in Malaysia," New Mandala, www.newmandala.org/the-ups-and-downs-of-islamic-education-in-malaysia/ accessed on 6 June 2018.

46 Fauziah Fathil and Wiwin Oktasari, "Religious Education and Containment of Radical Elements: The Case Of Pondok Schools in Malaysia," International Journal of Islamic and Civilizational Studies, 1, 10 (2017): pp. 60-70.

47 New pride for sekolah pondok, The Star Online, Retrieved from https://www.thestar.com.my/news/education/2013/11/10/new-pride-for-sekolah-pondok, accessed on 2 May 2019.

48 Asmawati Suhid, "Strengthening and Transformation of the Islamic Education System in Malaysia," Tarbiya: Journal Of Education In Muslim Society, 5, 1 (June 2018): pp. $71-72$
} 
Islamic sciences, some combine with integrasi Akademik (national curriculum), and others provide formal secondary religious education. The number of this tahfiz in 2011 report by Jabatan Kemajuan Islam Malaysia (JAKIM, Department of Islamic Development Malaysia) was 278 , and 254 of which are privately funded. ${ }^{49}$ This number has multiplied several times in 2017 as about 1.200 tahfiz institutions are recorded according to Associations of al-Quran Tahfiz Institutions. ${ }^{50}$

\section{Curriculum of Islamic Schools in Indonesia and Malaysia: Evidences from the Ground}

For this research, three Indonesian Islamic education institutions and two Malaysian counterparts were visited. For Indonesia, those three are Madrasah Aliyah Negeri (MAN, Senior High Islamic School) Surabaya, Sekolah Menengah Atas (SMA, Senior High School) Darul Ulum 2 Cambridge International School located in Islamic boarding school at Rejoso Jombang and SMA Nahdlatul Ulama 1 Model (Senior High School NU 1 Model) at Karanggeneng Lamongan. Thus two education institutions are under ministry of Education and Culture located in pondok pesantrens, and one institution under Ministry of Religious affairs, not in pondok pesantrens.

MAN Surabaya is a state funded Islamic school institution. Its curriculum is set by government. There are five Islamic subjects for basic competence, they are (1) Al-Qur'an Hadis (the Holy Quran and prophet tradition);51 (2) Aqidah Akhlaq (Theology and Ethics); (3) Fikih (Islamic jurisprudence); (4) Sejarah Kebudayaan Islam (Islamic History); (5) and Arabic. For students who take Islamic studies as their major, which usually takes place in second year, there are additional six Islamic subjects they must study. They are the science of the Quran, the science of Hadith, Islamic legal theory, Theology, Ethics, and Arabic. For these subjects, delivery as well as textbooks are in Bahasa

\footnotetext{
49 Solahuddin Ismail, "Institusi Tahfiz di Malaysia: Prospek dan Cabaran," Conference Paper of International Simposium of Tabfiz al-Quran (Bangi Selangor: Institut Latiham Islam Malaysia (ILIM), November 2016), p. 4.

50 Trinna Leong, "Private Islamic schools mushrooming in Malaysia," The Strait Times, https://www.straitstimes.com/asia/se-asia/private-islamic-schools-mushrooming-inmalaysia, acessed on 4 September 2018.

51 The subject is usually thematically arranged. Usually, in every chapter there is a verse or two of the Quran as well as a narration of prophet tradition in the same topic. Basically, it is an interpretation of the Quran and hadith for selected topics, not a study of whole verses and chapter in the Quran nor whole narrations of prophet tradition.
} 
Indonesia, except textbook, for Arabic subject. The curriculum has been prepared by the Ministry of Religious Affairs and they are used widely by Madrasah Aliyah Indonesian-wide, both state owned and private.

The second school visited is Sekolah Menengah Atas (Senior High School) Darul Ulum 2 Cambridge International in Jombang, East Java. The decision to include Senior High School of Darul Ulum 2 Cambridge International School for the object of the research represents a type of pesantren based schools that integrates classical Islamic sciences with modern science. The school is located and managed by pondok pesantren Darul Ulum in Jombang East Java. Students of the school generally stay in the dormitory of pondok pesantren in which they also get additional Islamic instruction and habituation. Beside this school, pondok pesantren Darul Ulum also administers several other schools and madrasahs. It hosts three government funded madrasahs, namely MIN, MTsN, and MAN. In addition, it also administers SMP, SMA, SMK and a university with Islamic faculties and general faculties alike.

Pondok pesantren Darul Ulum established SMA Darul Ulum 2 in the 1970s. it is among the earliest Pondok Pesantren in Indonesia that opened education system other than madrasah. The leadership of Pondok Pesantren Darul Ulum took s strategic move to transform the school into a science-oriented school with the assistance of BJ. Habibie's BPPT in 1995 with the focus of science and technology. ${ }^{52}$ The school is trusted to be one of the schools in Indonesia to be projected as Rintisan Sekolah Menengah Atas Berstandar Internasional (R-SMA-BI, Pioneer of High School with International Standard). In Academic Year of 2013/2014, the school is awarded to be the pilot project for the implementation of Curriculum 2013, and then in 2014/2015, it is appointed to implement the National Examination Computer Based Test (CBT). SMA Darul Ulum 2 Jombang BPPT has kept improving their quality, ensuring their grades and establishing their cooperation with international institutes of education and experts

\footnotetext{
52 BPPT is abbreviation of Badan Pengkajian dan Penerapan Teknologi (Agency for the Research and Application of Technology). BPPT was established as a government agency non-ministry in 1978 and was headed by BJ. Habibie until 1998. This Agency is under the coordination of the Ministry of Research and Technology. One of the programs is to introduce and internalize the development of technology. The institution made programs for schools to develop and implement science-based.
} 
around the world for creating students and alumni who have an international scientific capabilities and steadfastness in fostering faith and devotion as listed on the school's vision and mission. On August 13, 2007, Cambridge University as the houses of CIE (Cambridge International Examination) has decided Senior High School Darul Ulum 2 BPPT Jombang as the CIC (Cambridge Intenational Centre). Thus, it can execute the Certification of Cambridge Examination for all students of junior high school/ high school grades, and who intend to take the international examination scale. In 2012, the name of CIC (Cambridge Intenational Centre) SMA DU 2 changed to SMA Darul Ulum 2 CIS (Cambridge International School). SMA Darul Ulum 2 Jombang develops its curriculum by adapting three curriculums at once, namely Pondok Pesantren curriculum, National Curriculum and Cambridge Curriculum. The goal is creating a new generation superior in Faith and Piety (Iman and Taqwa), Science and Akblaq al-Karimah (good attitudes) in both national and international levels.

To achieve those goals, several Islamic subjects are taught in classroom. They are; Ilmu Tajwid, Alquran Hadis (the Quran and Prophet Traditions), Aqidah Akhlak (Theology and Ethics), Fikih (Islamic Jurisprudence), Sejarah Kebudayaan Islam (Islamic History), Bahasa Arab/Nahwu sarf (Arabic grammar). Textbook modules are prepared by Pondok Pesantren Darul Ulum for teaching these subjects. In addition, some basic Islamic classical textbooks widely circulated in pondok pesantren (kitab kuning) ${ }^{53}$ are also employed. For instance, Matn Ghayah wa al-Taqrib and al-Tadzhib for Islamic jurisprudence, Ta'Tim alMuta'allim for Ethics, Aqidah al-Awam and Jawähir al-Kalämiyah for Theology, and Nazm Imriti matn Ajurumiyah, and Amtbilah al-Tashrifiyah for Arabic Grammar. In addition, several religious activities are conducted daily before schooling hours, such as devotional morning prayers (salah a-dhuha), devotional supplication called istighathah, and recitation of certain chapters of Holy Quran (Yasin, al-Waqiah, alMulk, etc). Students also requested to memorize certain chapters of the Holy Quran, especially Yasin and al-Waqi'ah, short chapters in the section $30^{\text {th }}$ of the Holy Quran, devotional supplications of tablil and

\footnotetext{
${ }^{53}$ For further account on Kitab Kuning, read Martin van Bruinessen, "Pesantren and kitab kuning: Continuity and change in a tradition of religious learning," Wolfgang Marschall (ed.), Texts from the islands: Oral and written traditions of Indonesia and the Malay world [Ethnologica Bernensia, 4], (Berne: The University of Berne Institute of Ethnology, 1994), pp. 121-146.
} 
istighäthah. SMA Darul Ulum 2 CIS is a full day school in 6 days stating from Saturday until Thursday. Friday is the day off.

The other school is SMA Nahdlatul Ulama 1 Model. Located in Karanggeneng Lamongan East Java. The school is managed by pondok pesantren Tanwirul Qulub. Beside this school, it also administers Madrasah Tsanawiyah and informal Islamic instructions. Similar to SMA Darul Ulum 2 CIS, students from distant residencies may reside in pondok pesantren and study Islam after schooling hours. The school wishes to integrate traditional Islamic teachings and science. In other word, the principle of the schools is the integration of religious and science. The vision of the school is to educate students becoming an accomplished person (insan kamil) by mastering religious teachings, science and technology altogether. Meanwhile, its visions are to develop learners in mastering: (1) skills in line with community needs and science development technology; (2) science and technology and application of the development of the globalization era; (3) national and Islamic culture comprehensively, (4) abklāq al-karimah (good attitudes) based on Islamic principles and values; and (4) Islamic teaching based on Abl al-Sunnah wa al-jamá $a b^{54}$ and applying them in their daily life.

To implement the vision, Senior High School NU 1 Model applies an integrated curriculum which develops Islamic traditional (salaf or salafiyah, of mainly Shafi'i school in jurisprudence and Ash'ari theology) subject matters with modern sciences. ${ }^{55}$ The school tries to maintain the existing on Islamic subjects and to adopt new subjects which are considered modern. By implementing the integrated curriculum, the students are expected to be high qualified graduates who master science and technology embedded with akblaq al-karimah based on Islamic principle and values. In addition, the school has also tried to equip students with English and Arabic language. It is due to the fact that the school has developed its networks with other schools in the

\footnotetext{
${ }^{54}$ Since the school is affiliated to the traditional Islamic group of Nahdlatul Ulama, the term of Abl al-Sunnah wa al-Jamä'ah refers Ash'ariyah theology, four sunni school of law with Shafii school as heavy favorite, and and Sufism of al-Junayd and al-Ghazali. See for instance, a booklet written by Achmad Siddik who was an intellectual mastermind of Nahdlarul Ulama in the 1980s, entitled Khittah Nabdliyah (Surabaya: Khalista, 2005).

55 The term Salaf or salafiyah in this context should not be confused with salafi which is a textual approach to Islam rooted in Wahhabi theology. Read a concise explanation of this in Martin van Bruinessen, "Traditionalist and Islamist Pesantrens in Contemporary Indonesia, p. 222.
} 
USA and ASEAN countries, particularly Islamic schools in Thailand. ${ }^{56}$ Therefore, the students are expected to be prepared to study and live overseas. On the other hand, the students at the school are also able to communicate and study together with foreign students through network that has been built by the school.

To achieve this goal, the school has a strict policy to recruit highqualified teachers for religious subjects. There are several abilities required to the candidates of new teachers. In addition to the basic requirement of being a teacher, the school will select the candidates based on their ability in reciting the Holy Qur'an and reading Kitab Kunings. Mastery of spoken Arabic is also considered to support muhadathah (Arabic speaking) program applied by the school. Besides, the school also considers the capabilities of the candidates in terms of entrepreneurship, life skill competence and leading tablil prayer, istighäthah and Maulid Dibai $i$ as well as manaqib al-Shaikh Abdul Qadir Jilani.

On the other hand, the two Malaysian schools studied in this research are Sekolah Menengah Kebangsaan Agama (SMKA, national religious secondary school) Darussaadah and Ma'had Tahfiz Sains Darul Muttaqin or MASDAR. Both Islamic education institutions are located in Kedah Darulaman, a stronghold of PAS (Parti Islam SeMalaysia). National Religious Secondary School Darussaadah represents schools fully financed by the federal government. On the other hand, MASDAR is a private school fully funded by a foundation; funding sources from tuition, donation and others, so it is a Sekolah Agama Rakyat (SAR, people's religious school). The following will discuss in detail of all aspects related to the research focus of each school.

Located in Kedah, SMKA Darussaadah was first established by Mr. Haji Hussin Hassan in 1918 in form of pondok, an informal Islamic education institution. During Japan occupation in 1942-1945, this pondok was relocated to the Kampong Tambak Bunga, Jalan Kuala Kedah and had operated since then. This pondok was transformed into

56 SMA NU I Model have conducted students and teachers exchange since 2007 among other things with Randolph Macon Human College, Virginia USA, Youth Islamic Leadership Program of CCE International at Colonial Williamsburg USA and ASEAN countries, including Thailand. They are many students from Thailand from different schools and areas who stay in the Islamic Boarding School and study at SMA NU 1 Model Karanggeneng Lamongan. 
madrasah, a formal Islamic school, with the name of Madrasah alHasanah led by Tuan Haji Othman Haji Abdullah and Tuan Haji Long bin Muhammad. In 1956, they agreed to change the name of the Madrasah al-Hasan into Madrasah Agama Darussaadah (Darussaadah Islamic Boarding School) and registered Kedah Islamic Religious Department. Since June 2005, SMKA Darussaadah elected to be Sekolah Agama Bantuan Kerajaan" (SABK, government-assisted religious schools) and its leadership is held by posterity of the founder of the school, namely Haji Abdul Rashid bin H. Othman. Thus, the status of Darussaadah high school is no longer a private school,but it is a public school that the operational funding becomes the government responsibility.

The vision of SMKA Darussaadah is "quality education, human well-educated, prosperous country". The mission of the school is "to preserve the quality of the education system, to develop individual potential, to meet the aspirations of the country," while the objectives (goals) schools are: (1) to lead, manage and govern the school effectively and efficiently; (2) strengthen the moral and the skills of students; (3) Enhance the students' achievement in extra-curricular; (4) Provide safe, cheerful and conducive school infrastructure; (5) strengthen the implementation of an new integrated curriculum; (6) create a professional and integrated Ulama; and (7) create creative and innovative students

To prove the vision, missions and objectives above, a curriculum package is created by the Darussaadah high school that includes the curriculum level 1 to level 6 . The curriculum is a combination between regular and religious curriculum. It is implemented from level 1 to 5, while level 6 is the preparatory stage to the university, and it is special for those who will continue their studies to al-Azhar, Cairo, Egypt. The curriculum starts levels 1 through 6 as follows.

For the level I and II, the subjects delivered consists of 9 subjects of general curriculum and 2 religious subjects. The 9 subjects from general curriculum are Malay language, English, Mathematics, History, Geography, Science, Life skill, Visual Arts Education, Physical Education and Health. While the two subjects related two religious matter are Ushuluddin and Arabic (lughah Arabiyyah Mu'asira). For the level III, the students will learn Malay, English, Mathematics, History, Geography, Science, Living Skill, Islamic Education, Physical Education and Health. In addition, the students has an obligation to 
religious subjects which are consists of Ushūluddin Tawhịd, Ushūluddin Tafsir, Hadith Ushūluddin, Sharia Quran, Sharia Fiqh, History of Islamic Sharia, Grammar and Sarf, Muțala'ah and General Arabic.

For students of level IV and V, they have to study at least 13 subjects from general curriculum (Malay, English, Arabic, Mathematics, History, Science, Syariah Islamiah, Education - Qur'an Sunnah, Additional Mathematics, Trade, Accounting Principles, Economics, and Physical and Health Education) and 11 religious subjects (Quran Recitation, Fiqh Faraid, Tawhid Mantiq, Tafsir, Hadith, Arabic Grammar and Sarf, Mutalaah, Jurisprudence, Do-Don'ts nusus, Balaghah, and Arudh Qafiyah). While for the sixth level, they study religious subjects (Quran Recitation, Fiqh Faraid, Tafsir, Hadith, Arabic Grammar and Sarf, Insha' Mutala'ah, Contemporary Arabix literature, Balaghah, Tawhid Mantiq, Arudh Qafiyah, Ulum al-Quran, Ulum al-hadith, English, and Jurisprudence). The subjects are as follows.

It can be seen that the higher the level, the more religious lesson is given, even at the level of the 6th all of the material is oriented for the students who are eager to continue their studies to al-Azhar University in Egypt. At level I and II there are only two religious subjects given. When they continue to $3^{\text {rd }}$ level, the number of religious subjects given is eight (8), in addition of 1 lesson of Islamic education and Arabic lesson. At level 4 and 5, there are 11 religious materials added with some subjects like Arabic, Islamic education Islam, the Qur'an and Hadith. And for $6^{\text {th }}$ level all of the materials are religious material.

Based on the curriculum that has been prepared at Darussaadah high school, the obligation of religious teachers is according to the curriculum set and based on the Turath book (yellow books or old books) and Arabic is the language used to give instruction in the classroom, especially at the level of 6 . Thus, the competencies required to teach religious subjects as stated above are mastery of the material following the teaching of religious education branches, ability of reading the Turath books, mastery Arabic and proficiency of Malay language.

The second institution is Ma'had Tahfiz Sains Darul Muttaqin (MASDAR) located at Lot 2215, Mukim Termin Kubang Pasu, Kedah Darulaman. MASDAR school was established in 2012 and officially started the learning process on January 8, 2012. MASDAR is a fully 
private institution. However, as an educational institution, MASDAR is managed by the foundation of Nazir Human Development Cooperative Trust Northern Territory (KOINSAN).

The establishment of MASDAR are aimed at: (a) preparing and producing religious generation who have the ability to memorize and master the contents of the holy Quran beside the science (Islamic law) and academic (reality); (b) providing a platform to carry out Islamic propagation work (dakwa) and education to spread Islam through institutions; (c) creating huffaz (people who memorize al-Qur'an) who have commendable character and has the mental and physical quotient; and (d) Generating coatings that dominate the leadership of al-Quran and have the knowledge and skills needed to perform various tasks as $d a ' i$ (preacher) and murabbi (educator). The subjects taught in MASDAR can be categorized into three specific subjects, that are 24 schooling hours of diniyah or religious subjects (Tafsir, Hadith, Tawheed, Fiqh, Sirah, Mutala'ah, Akhlaq, Arabic Dictation \& writing, Grammar \& Sarf, Interpretation and Mutala'ah, skills of al-Qur'an), 24 schooling hours of academic education (English, Science, Mathematics, Physic Education \& Health, Integrated Living Skills, Arabic, History, and Geography) and 37 schooling hours of tabfiz (memorizing the Qur'an).

\section{Whither of Islamic Education? Between Integration and Piety}

Before embarking into some analytical detail, it is advisable to explaining the schools and madrasah in Indonesia and Malaysia. In Indonesia, there are two types of primary education; namely Sekolah Dasar (SD, elementary school) and Madrasah Ibtidaiyah (MI, Elementary Islamic School). Some of this type of education is funded by the government or by private. This would correspond to Malaysia's Sekolah Rendah Kebangsaan (SRK, Malay Primary School) and Sekolah Rendah Agama (religious Islamic School) respectively. There is also Sekolah Agama rakyat (SAR, People's Religious School) which is mainly funded by the states. The education lasts for six years. In secondary level of education, things get complicated since Indonesia recognizes two levels of schooling. They are Sekolah Menengah Pertama (SMP, Junior High School) and Madrasah Tsanawiyah (MTs, Junior High Islamic School). It takes 3 years to finish the education before continuing to senior levels, they are Sekolah Menengah Atas (SMA, Senior High School) and Madrasah Aliyah (MA, Senior high Islamic School). This 
takes another 3 years to finish before being eligible to enroll in tertiary education. In Malaysia, there is one level secondary education which lasts 5 years, but provided by different types of schools. They are Sekolah Menengah Kebangsaan (SMK, National secondary school), Sekolah Menengah Kebangsaan Agama (SMKA, National religious secondary school), Sekolah Agama Negeri (SAN, State religious schools), and Sekolah Agama Bantuan Kerajaan (SABK, Government aided Secondary School). One year of matriculation is needed by graduates of these secondary education before continuing education to tertiary education by taking Sijil Tinggi Agama Malaysia (STAM, Malaysia High Certificate of Religious Study)

The nature of integration between Islamic and non-Islamic education is sharply different between the two countries. Given the different political configuration, Indonesia, in which is Islam is one of several officially recognized religions, integration is reasonably shallow to say the least. When referring to the regulatory framework of education in Indonesia, the function of religious education is to prepare students as part of community members who understand and apply religious values and/or become expert of religion. It further states that Religious education could be held at formal, non-formal, and informal education. ${ }^{57}$ Thus, it could be inferred that religious education in national schools is limited to prepare students as part of community members who understand and apply religious values, not an extent to become expert of religion. This conclusion is confirmed by a statement of Director General of Islamic Education as he once said that the objective of religious education in national schools is mainly to build religious character of students so they are committed to observe their religion. ${ }^{58}$ Thus, there is no need for much schooling hours for studying various kinds of religious subjects, two schooling hours per week is deemed enough. Indeed, studying many aspects of religion in details should be done in in madrasah (Islamic School) and other kinds of religious education.

In contrast, Malaysia, in which Islam is the official religion, put heavy attention on providing Islamic instruction in public schools. A

\footnotetext{
57 Achmad Asrori, "Contemporary Religious Education Model on the Challenge of Indonesian Multiculturalism," Journal of Indonesian Islam, 10, 2 (December 2016), p. 269.

58 Muchlishon Rochmat, 'Dua Alasan Pendidikan Agama Tetap Diajarkan di Sekolah, NU Online,' https://www.nu.or.id/post/read/83065/dua-alasan-pendidikan-agamatetap-diajarkan-di-sekolah, accessed on 1 September 2018.
} 
special agency for ensuring good delivery and program of religious education in national schools is set up. It creates curriculum and many other steps it needs to ensure the integration of Islamic education into national school as well as its sufficiency. Admittedly, this move coincides with many supporting forces. The majority of highly conscious Malaysian Muslim community have arrived into conclusion that Islam should be learned and implemented in every step of the way. They demand that education should cater Islamic education hand in hand with secular education. Government should heed this demand for at least two reasons. Approving aspiration of majority Muslim community is politically correct. This would prevent the likeliness of people from changing votes to a more conservative opposition, PAS. Furthermore, fulfilling this demand is better off than seeing parents herding their children to religious schools.

It should be cleared from the beginning that there is nothing wrong with Malaysian religious schools, but Malaysia need more than just 'Ulamā' and clerics. In fact, these schools have performed as they should in producing 'Ulamā', clerics and other religious functionaries. As the curriculum shows, it was crafted in such a way that enables graduates to pursue further studies in mainly middle eastern countries. The emphasis on the mastery of Arabic as there are plenty of hours dedicated to study Arabic and its related disciplines (Arabic Grammar and Sarf, Inshā'-Mutāla'ah, Contemporary Arabic literature, Balaghah, Mantiq, Arudh Qafiyah,) confirms that. The existence of non-Islamic subjects as the government curriculum has mandated do not put Islamic subject aside. The allocation of Islamic subjects remains relatively substantial to a degree that the mastery of basic Islamic sciences is achieved at least to a level that being eligible to pursue tertiary Islamic studies.

In contrast, curriculum in Indonesian's Madrasah Aliyah does not seems directly has that orientation, at least when middle eastern universities as targeted destination in mind. With the curriculum of $30 \%$ of Islamic subjects and $70 \%$ of non-Islamic subject, employability rather than integration, is apparently more accentuated. The decision for opening MAN-IC and the presence of plenty of national schools in pondok pesantrens further convince this. However, several pathways are available for those who wish to focus studying Islam, namely Madrasah Aliyah Program Khusus (MA-PK), MAN Model, and pondok pesantrenbased madrasah or school. While the seat of Islamic higher education 
in Indonesia is virtually limitless, the demand for studying Islam in middle eastern tertiary universities is always high. ${ }^{59}$

Certainly, among the major reason for this difference has something to do with the outlook of Islam in Indonesia and Malaysia. While a distinct research should be done on this respect, some hints could be put forward, namely the status of Islam in Malaysia as official religion albeit strong presence of Chinese and Tamil minorities. Likewise, Islamic surge starting in the 1970s has deeply influenced and shaped Malaysian Muslims to a certain degree that Islamic representation should be prevalent in all walks of life in a very identified way. The government, either state or federal, in the effort to win the heart and mind of Muslims do their best to show their commitment to Islam in their programs. In contrast, Indonesia experience a whole different story as Islam in not the only officially recognized religion. Muslims also sharply divided among traditional, modern, nominal, secular, and liberal to say the least. They often have different articulation about Islam or about religion in general. NonMuslims also have voice in Indonesia. Admittedly, there has been 'conservative turn' among Muslims in Indonesia these recent years, but so far has not yet become mainstream and only affect certain elements of Muslim community in Indonesia.

\section{Conclusion}

Islamic education in Indonesia and Malaysia originated from the very identical root, pondok pesantren. However, as the story goes they went different ways. After its initial transformation into madrasah, with some pros and cons certainly, colonial and political context has shape Islamic education in Indonesia administered in a separate ministry and finally formed a curriculum that enable graduates to endeavor not only in religious fields but also in all walks of life. Whereas mainstream madrasah in Malaysia stick to their guns in Islamic studies. All students in Indonesia and Malaysia, though, regardless of their schools, must study religion with different gradation. While Islamic instruction in

59 Ministry of Religious Affairs and some other private institutions regularly hold selection process for those who wish to pursue tertiary education in middle eastern countries with abundant of participants. See for instance, Kementerian Agama RI Ditjen Pendidikan Islam, Direktorat Pendidikan Tinggi Keagamaan Islam, Seleksi Beasiswa dan Non-Beasiswa S1 Peguruan Tinggi Luar Negeri Timur Tengah (Mesir, Maroko, Sudan dan Libanon), http://diktis.kemenag.go.id/timteng12/017/, accessed on 6 May 2019. 
Indonesian schools is supplied only to shape religious character, Malaysian schools endeavor a form of integration between Islamic and non-Islamic sciences. Pondok pesantrens too, have developed to a degree that differing features do occur, although they share several resemblances. Their private natures enable pondok pesantrens to innovate beyond limit, but remain a deeply rooted Islamic education institutions in both countries. The difference on the orientation and status of Islamic education between Indonesia and Malaysia reflects how Islam has evolved in two countries given local political context and international drives.]

\section{References}

\section{Books and Articles}

Ahid, Nur. "Problem Pengelolaan Madrasah Aliyah dan Solusinya". Islamica. 4, 2 (March 2010).

Asrori, Achmad. "Contemporary Religious Education Model On The Challenge of Indonesian Multiculturalism". Journal of Indonesian Islam. 10, 2 (December 2016).

Azra, Hidayatullah. "Islamic Education in Indonesia". Holger Daun and Reza Arjmand (eds). Handbook of Islamic Education. Cham: Springer International Publishing AG: 2018.

Castle, Lance, "Notes on the Islamic School at Gontor". Indonesia. 1, 1 (1966).

Fathil, Fauziah and Wiwin Oktasari. "Religious Education and Containment of Radical Elements: The Case of Pondok Schools in Malaysia". International Journal of Islamic and Civilizational Studies. 1, 10 (2017): pp. 60-70.

Ghozali, Abbas, et al. Madrasah Education Financing in Indonesia. Jakarta: ACDP, 2013.

Habibi, Ibnu. "Muhammadiyah Boarding School (MBS) Sebagai Alternatif Model Pesantren (Potret Pendidikan Islam di Era Kontemporer)". Proceedings of $1^{\text {st }}$ Annual Conference for Muslim Scholars. Surabaya: Kopertais Wilayah IV Surabaya, 2017. 
Hamid, Ahmad Fauzi Abdul. "Islamic Education in Malaysia". Holger Daun and Reza Arjmand (eds). Handbook of Islamic Education. (Cham: Springer International Publishing AG: 2018).

Hasan, Noorhaidi. "The Salafi Madrasas of Indonesia". Farish A. Noor, Yoginder Sikand and Martin van Bruinessen (eds). The Madrasa in Asia: Political Activism and Transnational Linkages. (Amsterdam: ISIM/Amsterdam University Press, 2008).

Hashim, Rosnani, “The reformation of Muslim education In Malaysia: ensuring relevance and overcoming challenges". International Symposium of Imam-Hatip (Vocational Religious) Schools in their Centennial Anniversary. Istanbul, Turkey: November 23-25th 2013.

Hashim, Rosnani, Suhailah Hussien and Juhasni Adila Juperi. "The Hikmah (Wisdom) Program: A philosophical inquiry for the teaching of Islamic education in Malaysia". Sa'eda Buang and Phyllis Ghim-Lian Chew (eds). Muslim Education in the 21st Century: Asian perspectives. Oxon: Routledge, 2014.

Ichwan, Moch Nur. "Towards a Puritanical Moderate Islam: The Majelis Ulama, Indonesia and the Politics of Religious Orthodoxy". Contemporary Developments in Indonesian Islam Explaining the 'Conservative Turn'. Singapore: Institute of Southeast Asian Studies, 2013.

Ismail, Solahuddin. "Institusi Tahfiz di Malaysia: Prospek dan Cabaran". Conference Paper Simposium Tahfiz al-Quran Peringkat Antarabangsa, At Institut Latiham Islam Malaysia (ILIM) Bangi Selangor, November 2016.

Kelabora, Lambert. "Religious Instruction Policy in Indonesia". Asian Survey. 16, 3 (March 1976).

Kosim, Mohammad. "Madrasah di Indonesia (Pertumbuhan dan Perkembangan)". Tadris. 2, 1 (2007).

Kraince, Richard G. "Reforming Islamic Education in Malaysia: Doctrine or Dialogue?". Robert W. Hefner (ed). Making modern Muslims : the politics of Islamic education in Southeast Asia. Hawai'i: University of Hawaici Press, 2009). 
Kushimoto, Hiroko. "Islam and Modern School Education in Journal Pengasuh: Review of the Kaum Muda - Kaum Tua Dichotomy”. Studia Islamika. 19, 2 (2012): pp. 207-250.

Maarif, Nurul H., Gamal Ferdhi and A. Suaedi. "Memecah Kebekuan Regenerasi Ulama". Gatra, 12 February 2006.

Nurochim. "Sekolah Berbasis Pesantren Sebagai Salah Satu Model Pendidikan Islam Dalam Konsepsi Perubahan Sosial". Al-Tabrir. 16, 1 (May 2016): pp. 80-85.

Othman, Nooraini and Khairul Azmi Mohamad. "Eclectic Model in the Malaysian Education System". International Education Studies. 4, 4 (November 2011).

Siddik, Achmad. Khittab Nabdliyah. Surabaya: Khalista, 2005.

Steenbrink, Karel E. Pesantren Madrasah Sekolah: Pendidikan Islam dalam Kurun Moderen. Jakarta: LP3ES, 1986.

Suhid, Asmawati. "Strengthening and Transformation of the Islamic Education System in Malaysia". Tarbiya: Journal Of Education In Muslim Society. 51 (June 2018).

Sukarno, Makmuri. "Mengembangkan Madrasah Aliyah Negeri Insan Cendekia Untuk Menjawab Tantangan Modernisasi, Demokratisasi Dan Globalisasi”. Jurnal Kependudukan Indonesia. 9, 2 (Desember 2014).

Tolchah, Moch. "The Political Dimension Of Indonesian Islamic Education In The Post-1998 Reform Period". Journal of Indonesian Islam, 8, 2 (2014): pp. 284-298

van Bruinessen, Martin. "Traditionalist and Islamist Pesantrens in Contemporary Indonesia". Farish A. Noor, Yoginder Sikand and Martin van Bruinessen (eds). The Madrasa in Asia: Political Activism and Transnational Linkages. Amsterdam: ISIM/Amsterdam University Press, 2008).

van Bruinessen, Martin. "Pesantren and kitab kuning: Continuity and change in a tradition of religious learning". Wolfgang Marschall (ed.). Texts from the islands: Oral and written traditions of Indonesia and the Malay world [Ethnologica Bernensia, 4]. Berne: The University of Berne Institute of Ethnology, 1994. 
Zain, Mat F, WK Mujani and IA Bakar. "The Islamic education and the ' $\mathrm{j}$-QAF' program in Malaysia". Advances in Natural and Applied Sciences. 6, 3, Special Issue 2 (2012).

\section{Internet Sources}

Info Peminatan (Jurusan), official website of MAN 1 Jakarta, http://www.man1.sch.id/ppdb2019/info.php

Leong, Trinna, 'Private Islamic schools mushrooming in Malaysia,' The Strait Times, https://www.straitstimes.com/asia/se-asia/privateislamic-schools-mushrooming-in-malaysia, acessed on 4 September 2018.

Ministry OF Religious Affairs Republic of Indonesia-Directorate general of Islamic Education, Direktorat Pendidikan Tinggi Keagamaan Islam, Seleksi Beasiswa dan Non-Beasiswa S1 Peguruan Tinggi Luar Negeri Timur Tengah (Mesir, Maroko, Sudan dan Libanon), http://diktis.kemenag.go.id/timteng12/017/, accessed on 6 May 2019.

New pride for sekolah pondok, The Star Online, Retrieved from https://www.thestar.com.my/news/education/2013/11/10/ne w-pride-for-sekolah-pondok, accessed on 2 May 2018.

NU online. "Inilah 13 Machad Aly yang Diresmikan oleh Menteri Agama". $\quad$ https://www.nu.or.id/post/read/68634/inilah-13mahad-aly-yang-diresmikan-oleh-menteri-agama, 30 May 2016.

Rochmat, Muchlishon. "Dua Alasan Pendidikan Agama Tetap Diajarkan di Sekolah". NU Online. https://www.nu.or.id/post $/ \mathrm{read} / 83065 /$ dua-alasan-pendidikan-agama-tetap-diajarkandi-sekolah, accessed on 1 September 2018.

Tayeb, Azmel. "The ups and downs of Islamic education in Malaysia". New Mandala. www.newmandala.org/the-ups-and-downs-ofislamic-education-in-malaysia/, accessed on 6 June 2018.

The Straits Times. "PM Mahathir to overhaul Malaysia's schools, saying too much focus on Islamic studies now". https://www.straitstimes.com/asia/se-asia/pm-mahathir-to-overhaul-malaysias-schools-saying-too-much-focus-on-islam-studies-now, $\quad 22$ December 2018. 